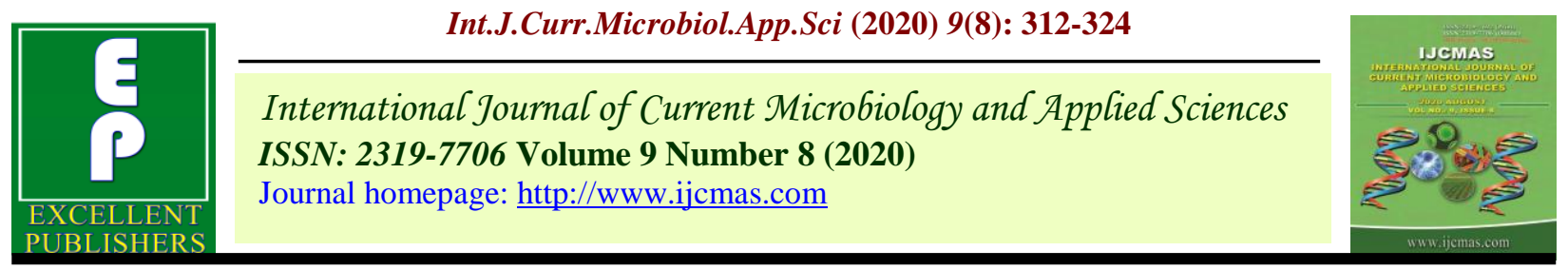

Original Research Article

https://doi.org/10.20546/ijcmas.2020.908.037

\title{
Semen Characteristics of NARI Suwarna Rams during Breeding (Winter) and Non-breeding (Summer) Seasons
}

\author{
Venkanagouda Doddagoudar*, M. K. Tandle, R. G. Bijurkar, N. A. Patil, \\ Ashok Pawar, Shrikant Kulkarni and Vinay Tikare
}

Veterinary College, KVAFSU, Nandinagar, Bidar, Karnataka, India

*Corresponding author

\begin{tabular}{|c|c|}
\hline & A B S T R A C T \\
\hline Keywords & \multirow{4}{*}{$\begin{array}{l}\text { The NARI Suwarna ram, a triple cross sheep strain known to carry the } F e c B \text { gene } \\
\text { was evaluated for seasonal variations in seminal characteristics during breeding } \\
\text { (winter) and non-breeding (summer) seasons. In the study, semen samples from } \\
\text { five sexually mature rams were evaluated for various seminal parameters, the live } \\
\text { sperm percentage was significantly }(\mathrm{p}<0.05 \text { ) higher during breeding (winter) } \\
\text { season whereas other semen characteristics viz. semen volume, colour, wave } \\
\text { motion, individual motility, sperm concentration, acrosome integrity, sperm } \\
\text { abnormalities did not show any significant variation ( }>0.05 \text { ) between or within } \\
\text { breeding (winter) and non-breeding (summer) seasons. Hence, it is concluded that } \\
\text { NARI Suwarna rams can produce equally good quality semen in winter as well as } \\
\text { summer seasons. }\end{array}$} \\
\hline $\begin{array}{l}\text { NARI Suwarna, } \\
\text { ram, Semen } \\
\text { characteristics, } \\
\text { Seasonal variation }\end{array}$ & \\
\hline Article Info & \\
\hline $\begin{array}{l}\text { Accepted: } \\
\text { 10 July } 2020 \\
\text { Available Online: } \\
10 \text { August } 2020\end{array}$ & \\
\hline
\end{tabular}

\section{Introduction}

Many sheep breeds do have a fairly well documented gonadal activity cycle which is influenced mainly by photoperiod (GómezBrunet et al.,2008) and high latitudes (Sarlós et al., 2013). NARI-Suwarna is a strain of sheep developed by Nimbkar Agricultural Research Institute (NARI), Phaltan, Maharashtra with $90 \%$ Deccani or $60 \%$ Deccani $+30 \%$ Madgyal and 10\% Garole breed proportions. It is known to inherit $\mathrm{FecB}$ gene from the Garole breed capable of producing and raising twin lambs, hence improving profitability in sheep farming.
Seasonal variability in different breeds is found to be influenced by the latitudes where animals are raised, higher the latitude in the northern hemisphere, greater was the seasonality (Abecia et al., 2012). However, in tropical regions, other ambient factors such as ambient temperature, relative air humidity, rain distribution and nutrition seem to have effects on reproductive physiology in seasonal animals (Rosa and Bryant, 2003).Some studies have reported seasonal variability in tropical and subtropical breeds (Santos et al., 2015; Belkadi et al., 2017) whereas others have reported no seasonal variability (Benmoula et al., 2017; Malejane et al., 2014) 
except for minor variations. Previous studies have reported some of the seminal characters in NARI Suwarna rams (Kadaganchi 2017; Jasrotia 2018; Muniyappanavar et al., 2020) but did not study seasonal variability of these characters which may hold the key in the ability to preserve its semen for longer durations so that it can be used for upgradation or crossbreeding of local sheep to improve their reproductive efficiency. The studies on seasonal changes in the seminal quality of Indian sheep breeds in general and NARI Suwarna rams in particular are scarce. Hence, the present study was conducted to evaluate the seasonal changes in NARI Suwarna ram semen.

\section{Materials and Methods}

\section{Location and selection of animals}

The study was carried out at Department of Veterinary Gynaecology and Obstetrics, Veterinary College, Bidar, Karnataka, India which lies between $17^{\circ} 35^{\prime}$ and $18^{\circ} 29^{\prime}$ North latitude and $76^{\circ} 41^{\prime}$ to $77^{\circ} 39^{\prime}$ ' East longitude. The study period extended over six months from December-2018 to May 2019 and split equally into two seasons, winter from December-2018 to Feb-2019 and summer from March to May-2019. Five sexually mature NARI Suwarna rams maintained under semi-intensive housing system with free grazing for 5-6 $\mathrm{h}$ daily and fed concentrate sheep feed at 200 g per day along with routine deworming and vaccinations were used for semen collection.

\section{Semen collection}

Semen was collected twice in a week using ram as a dummy with the artificial vagina (AV) as per the standard procedure during early morning hours before feeding throughout the study period. Soon after collection, the semen collection tubes marked and transferred to a water bath at $36^{\circ} \mathrm{C}$ (Plate
1 and 2).

\section{Semen Evaluation}

The semen volume was measured using a graduated collecting tube $(0.1 \mathrm{ml}$ accuracy $)$ soon after collection and samples with foreign material or abnormal colour were rejected.

For wave motion, a drop of neat semen placed on a pre-warmed glass slide $\left(37^{\circ} \mathrm{C}\right)$ without any coverslip, examined directly under the microscope $(100 x)$ and the wave motion was scored on a scale of 1-5 (Rahman 2014).

The individual motility of spermatozoa was assessed by placing a coverslip on a drop of diluted semen $(10 \mu \mathrm{l}$ semen mixed with $200 \mu \mathrm{l}$ normal saline) on a clean glass slide under the microscope with biothermal stage attached. The motility was observed under high power at400X magnification at 5 different fields and averaged and expressed in terms of percentage of progressively (0-100)motile sperm (Rahman, 2014).

The sperm concentration was expressed as the total number of spermatozoa in millions $\left(10^{6}\right)$ per $\mathrm{ml}$ of neat semen. Sperm concentration in semen was determined by using an improved Neubauer counting chamber after dilution of semen with 1:1000 with diluting fluid (Perumal et al., 2017). The sperm concentration was calculated using the formula

Number of sperm $/ \mathrm{ml}=\frac{N \times D \times 4}{n}$ million sperm

Where $\mathrm{N}=$ Number of spermatozoa counted; $\mathrm{D}=$ Dilution rate; $\mathrm{n}=$ number of tertiary squares counted.

To ascertain the percentage of live spermatozoa, semen mixed (1 drop) with one drop of Eosin (2\%) and one drop of Nigrosin $(10 \%)$ and smears were prepared within 30 
seconds of mixing and examined under oil immersion objective (1000X) after air drying (Srivastava and Pande, 2017). All stained and partially stained spermatozoa were considered as dead and the unstained spermatozoa as live (Plate 3). The percentage of live spermatozoa was determined by counting at least 200 spermatozoa.

Acrosome integrity was evaluated by using Giemsa stain, a small drop $(10 \mu \mathrm{l})$ of each sperm sample was placed on a grease-free slide and a drop $(30 \mu 1)$ of Sorenson's phosphate buffer was mixed with it and a smear was prepared. Then air-dried smears were placed in Hancock's fixative for 15-20 min in Coplin jar. Post-fixation, the slides were washed under slow-running tap water for another 15-20 min followed by washing with distilled water. Finally, the slides were placed in a Coplin jar containing Giemsa working stain and left overnight at $37{ }^{\circ} \mathrm{C}$. On next morning, the slides were removed, washed with slow-running tap water and finally with distilled water, air-dried and were observed under oil immersion at a total magnification of $1000 \mathrm{X}$. A total of two hundred spermatozoa were counted and the percentage of intact acrosome was calculated in the neat semen samples (Watson, 1975) (Plate 4).

Hypo-osmotic swelling of spermatozoa were evaluated by incubating semen samples with test $(150 \mathrm{mOsm} / \mathrm{L})$ and control $(300$ $\mathrm{mOsm} / \mathrm{L}$ )solutions in a water bath at $37^{\circ} \mathrm{C}$ for 30 minutes followed by examining a small drop of sample under phase contrast microscope at 400x and curled sperms counted as positive HOST and others as negative(Plate 5 and 6). The proportion of swollen sperm in the control samples were subtracted from the proportion of swollen sperm in the HOST solution, the resultant figure was considered as a percentage of HOST reactive spermatozoa (Jeyendran et al.,
1992).

Rose Bengal stain (3\%) was used for counting the percentage of normal and abnormal sperm (Pervage et al., 2009). Two drops of sodiumcitrate buffer were placed on a clean dry glass slide; one drop of mixed semen was added and spread by covering with another slide. The slide was dried in the air and stained with Rose Bengal stain for 15-20 minutes, excess stain rinsed by dipping the slide in distilled water. The slide with smear was dried in the air and observed under a microscope with oil immersion magnifications (1000X) for various sperm abnormalities by counting two hundred spermatozoa and the percentage was calculated (Plate 7).

\section{Results and Discussion}

\section{Weather data for breeding (winter) and non-breeding (summer) seasons during the study period}

The weather data, temperature (max \& min), relative humidity (RH), bright sunshine hours (BSSH) and rainfall from December 2018 to May 2019 was collected from Agriculture Research Station, Halladkeri, Bidar, Karnataka, India and is presented in Figure 1.The minimum and maximum temperatures along with relative humidity showed appreciable variation between the seasons whereas, bright sunshine hours were slightly lower for winter season and both seasons had similar low total rainfall (Figure 2).

Volume, colour, wave motion and individual motility

The semen volume, colour, wave motion and individual motility did not show any significant variation $(p>0.05)$ between or within breeding (winter) and non-breeding (summer) seasons in NARI Suwarna rams (Table 1). These findings are in line with 
studies of Cárdenas-Gallegos et al., (2012) and Benmoula et al., (2017)reporting no seasonality for semen volume, wave motion and individual motility in different breeds of rams. Further, the observed colour of semen as creamy white was in agreement with earlier reports for NARI Suwarna ram semen by Kaimal (2015), Kadaganchi (2017), Jasrotia (2018) and Muniyappanavar (2019) as creamy to creamy white colour.

In contrast, studies have reported significant seasonal variation for volume, colour, wave motion and individual motility in Hamdani rams (Juma and Al-Kassab, 2009) and increased semen volume in summer, semen colour being milky to creamy during summer and spring while having a thin density in autumn and winter with higher mass motility and individual motility in the summer season. Similar seasonal variations were also reported for volume, wave motion and individual motility in Dorper (Malejane et al., 2014), Naimi and Najdi rams (Al-Anazi et al., 2017). Further, some studies have reported seasonal variations for volume but not for wave motion and individual motility (Milczewski et al., 2015; Belkhiri et al., 2017) whereas, other studies have reported seasonal variations for wave motion and individual motility but not for semen volume (Chella et al., 2017).

The variations among the findings of different authors could be due to breed (Gündoğan 2007; Zamiri et al., 2010) and seasonal variations (Hamidi et al., 2012; Oláh et al., 2013) or age, method of semen collection and frequency of semen collection (Foote, 1978; Salhab et al., 2003; Malejane et al., 2014). Further, wave motion is usually seen as a superficial indication of the motility and viability of the sperm (O'Hara et al., 2010) and it is the function of sperm concentration along with motile sperm percentage (McGowan, 2019) and assessments are highly subjective and often have limited repeatability
(DeJarnette, 2005).

Sperm concentration, live sperm, plasma membrane integrity and acrosome integrity

The overall average live sperm percentage was significantly $(\mathrm{p}<0.05)$ higher in breeding (winter) than non-breeding (summer) season and plasma membrane integrity showed significant $(\mathrm{p}<0.05)$ variation only within non-breeding (summer) season but not between breeding (winter) and non-breeding (summer) seasons. The sperm concentration and acrosome integrity did not vary significantly $(\mathrm{p}>0.05)$ between or within breeding (winter) and non-breeding (summer) seasons in NARI Suwarna rams (Table 2).

The present findings of seasonal variability in live sperm percentage are consistent with the findings of higher viability noticed for winter in Ouled Djellal (Belkadi et al., 2017) and Zulu rams (Chella et al., 2017) and contradictory with the findings of lower viability noticed in winter for Ghezel and Mehraban (Zamiri and Khodaei, 2005), Dorper (Malejane et al., 2014) and Boujaad rams (Badi et al., 2018). Some studies have reported no seasonality for sperm viability as in INRA180 rams (Benmoula et al., 2017). Regarding HOST, the present findings are comparable with findings of Kaimal (2015) in NARI Suwarna rams with no seasonal variation but contradictory to Ntemka et al., (2019) with reported seasonal variation for sperm viability in Chios rams. Regarding sperm concentration and acrosome integrity, the present study is consistent with Azawi et al., (2012) in Awassi rams observing no variations between the seasons for both these parameters while for sperm concentration only with other workers (Kaimal 2015; Belkhiri et al., 2017; Benmoula et al., 2017; Ntemka et al., 2019). Further, in complete contrast to the present study, Azawi and 
Ismaeel (2012) reported seasonal variations with lower sperm concentration and viability with higher acrosomal damages during winter in Awassi rams. Similarly, Kumar et al., (2016) in Jakhrana bucks observed similar post-thaw HOST percentages between the seasons but significantly higher post-thaw acrosome integrity during the winter season. Further, D'Alessandro and Martemucci (2003) also observed significantly lower acrosomal damage during the breeding season in boars.

The variations in the live sperm percentage, concentration and acrosome integrity have been reported to vary due to methodological errors, feeding variation, breeds of rams and their adaptability in varying agro-climatic conditions of the places of investigation, season, frequency and method of semen collection (Oláh et al., 2013; Malejane et al., 2014). In the present study, plasma membrane integrity was varying only within the nonbreeding (summer) season which can be attributed to lower viability as observed in the summer resulting in higher dead sperm count releasing more ROS and damaging the plasma membrane from the resultant lipid peroxidation due to its high PUFA composition (Sikka, 2004; Ayala et al., 2014). However, this did result in the significant variation only within the summer season but not between the seasons, which could be due to variation in the adaptability of individual rams to higher temperatures during nonbreeding (summer) season.

\section{Sperm abnormalities}

The sperm abnormalities did not vary significantly $(\mathrm{p}>0.05)$ either between or within breeding (winter) and non-breeding (summer) seasons in NARI Suwarna rams.

Table.1 Volume, colour, wave motion and individual motility (Mean \pm Standard error) in fresh semen of NARI Suwarna rams during breeding (winter) and non-breeding (summer) seasons

\begin{tabular}{|c|c|c|c|c|c|c|c|c|c|}
\hline Parameters & \multicolumn{2}{|c|}{ Volume $(\mathbf{m L})$} & \multicolumn{2}{|c|}{ Colour } & \multicolumn{2}{c|}{ Wave motion (1-5) } & \multicolumn{2}{c|}{ Individual motility (\%) } \\
\hline Ram No. & Winter & Summer & \multicolumn{1}{|c|}{ Winter } & Summer & Winter & Summer & Winter & Summer \\
\hline $\mathbf{1}$ & $0.82 \pm 0.04$ & $0.90 \pm 0.04$ & $\begin{array}{l}\text { Creamy } \\
\text { white }\end{array}$ & $\begin{array}{l}\text { Creamy } \\
\text { white }\end{array}$ & $4.67 \pm 0.21$ & $4.67 \pm 0.21$ & $94.44 \pm 0.70$ & $95.00 \pm 0.74$ \\
\hline $\mathbf{2}$ & $0.77 \pm 0.04$ & $0.85 \pm 0.05$ & $\begin{array}{l}\text { Creamy } \\
\text { white }\end{array}$ & $\begin{array}{l}\text { Creamy } \\
\text { white }\end{array}$ & $4.67 \pm 0.21$ & $4.83 \pm 0.17$ & $96.11 \pm 0.56$ & $95.56 \pm 0.70$ \\
\hline $\mathbf{3}$ & $0.82 \pm 0.07$ & $0.85 \pm 0.07$ & $\begin{array}{l}\text { Creamy } \\
\text { white }\end{array}$ & $\begin{array}{l}\text { Creamy } \\
\text { white }\end{array}$ & $4.33 \pm 0.21$ & $4.50 \pm 0.22$ & $95.56 \pm 1.65$ & $97.22 \pm 0.56$ \\
\hline $\mathbf{4}$ & $0.77 \pm 0.05$ & $0.80 \pm 0.04$ & $\begin{array}{l}\text { Creamy } \\
\text { white }\end{array}$ & $\begin{array}{l}\text { Creamy } \\
\text { white }\end{array}$ & $4.50 \pm 0.22$ & $4.50 \pm 0.22$ & $96.67 \pm 1.72$ & $97.22 \pm 0.55$ \\
\hline $\mathbf{5}$ & $0.77 \pm 0.05$ & $0.83 \pm 0.05$ & $\begin{array}{l}\text { Creamy } \\
\text { white }\end{array}$ & $\begin{array}{l}\text { Creamy } \\
\text { white }\end{array}$ & $4.83 \pm 0.17$ & $5.00 \pm 0.00$ & $96.67 \pm 1.22$ & $95.56 \pm 0.70$ \\
\hline Overall & $0.79 \pm 0.02$ & $0.85 \pm 0.02$ & $\begin{array}{l}\text { Creamy } \\
\text { white }\end{array}$ & $\begin{array}{l}\text { Creamy } \\
\text { white }\end{array}$ & $4.60 \pm 0.09$ & $4.70 \pm 0.08$ & $95.89 \pm 0.54$ & $96.11 \pm 0.32$ \\
\hline
\end{tabular}


Table.2 Sperm concentration (million/mL), live sperm (\%), plasma membrane integrity (\%) and acrosome integrity (\%) (Mean \pm Standard error) in fresh semen of NARI Suwarna rams during breeding (winter) and non-breeding (summer) seasons

\begin{tabular}{|c|c|c|c|c|c|c|c|c|}
\hline \multirow{2}{*}{ Ram No. } & \multicolumn{2}{|c|}{$\begin{array}{c}\text { Sperm concentration } \\
\text { (million/mL) }\end{array}$} & \multicolumn{2}{|c|}{ Live sperm (\%) } & \multicolumn{2}{c|}{ Plasma membrane integrity (\%) } & Acrosome integrity (\%) \\
\cline { 2 - 9 } & Winter & Summer & Winter & Summer & Winter & Summer & Winter & Summer \\
\hline $\mathbf{1}$ & $4041 \pm 154$ & $3933 \pm 185$ & $92.42 \pm 0.96$ & $90.42 \pm 0.94$ & $71.67 \pm 1.66$ & $70.58 \pm 0.87^{\mathrm{AB}}$ & $96.17 \pm 0.42$ & $95.42 \pm 0.47$ \\
\hline $\mathbf{2}$ & $3783 \pm 138$ & $3725 \pm 602$ & $91.67 \pm 1.10$ & $90.83 \pm 1.16$ & $74.75 \pm 1.45$ & $73.75 \pm 1.38^{\mathrm{B}}$ & $96.75 \pm 0.53$ & $96.83 \pm 0.40$ \\
\hline $\mathbf{3}$ & $3516 \pm 159$ & $3758 \pm 164$ & $92.67 \pm 1.17$ & $91.25 \pm 1.02$ & $73.33 \pm 1.41$ & $73.25 \pm 1.22^{\mathrm{AB}}$ & $95.92 \pm 0.42$ & $96.50 \pm 0.83$ \\
\hline $\mathbf{4}$ & $3425 \pm 216$ & $3483 \pm 557$ & $93.75 \pm 0.80$ & $90.50 \pm 1.18$ & $74.00 \pm 1.09$ & $71.75 \pm 0.53^{\mathrm{AB}}$ & $95.67 \pm 0.64$ & $96.42 \pm 0.49$ \\
\hline $\mathbf{5}$ & $3608 \pm 182$ & $3658 \pm 123$ & $91.50 \pm 0.92$ & $91.50 \pm 0.89$ & $69.83 \pm 0.25$ & $69.42 \pm 0.96^{\mathrm{A}}$ & $95.00 \pm 0.52$ & $94.92 \pm 0.70$ \\
\hline Overall & $3675 \pm 82$ & $3711 \pm 60$ & $92.40 \pm 0.44^{\mathrm{a}}$ & $90.90 \pm 0.44^{\mathrm{b}}$ & $72.72 \pm 0.62$ & $71.75 \pm 0.52$ & $95.90 \pm 0.24$ & $96.02 \pm 0.28$ \\
\hline
\end{tabular}

Note: ${ }^{\mathrm{ab}}$ Different superscript between the columns vary significantly $(\mathrm{p}<0.05)$

${ }^{A B}$ Different superscript between the rows vary significantly $(\mathrm{p}<0.05)$

Table.3 Percent of sperm abnormalities (Mean \pm Standard error) in fresh semen of NARI Suwarna rams during breeding (winter) and non-breeding (summer) seasons

\begin{tabular}{|c|c|c|c|c|c|c|c|c|}
\hline \multirow{2}{*}{ Ram No. } & \multicolumn{9}{|c|}{ Sperm abnormalities (\%) } \\
\cline { 2 - 8 } & \multicolumn{2}{|c|}{ Head } & \multicolumn{2}{c|}{ Midpiece } & \multicolumn{2}{c|}{ Tail } & \multicolumn{2}{c|}{ Overall } \\
\cline { 2 - 8 } & Winter & Summer & Winter & Summer & Winter & Summer & Winter & Summer \\
\hline $\mathbf{1}$ & $0.50 \pm 0.22$ & $0.67 \pm 0.21$ & $0.50 \pm 0.22$ & $0.50 \pm 0.22$ & $3.50 \pm 0.81$ & $3.83 \pm 0.54$ & $4.50 \pm 1.02$ & $5.00 \pm 0.58$ \\
\hline $\mathbf{2}$ & $0.50 \pm 0.22$ & $0.50 \pm 0.22$ & $0.33 \pm 0.21$ & $0.17 \pm 0.17$ & $3.33 \pm 0.49$ & $3.83 \pm 0.31$ & $4.17 \pm 0.54$ & $4.50 \pm 0.22$ \\
\hline $\mathbf{3}$ & $0.33 \pm 0.21$ & $0.50 \pm 0.22$ & $0.67 \pm 0.21$ & $0.17 \pm 0.17$ & $3.67 \pm 0.67$ & $4.00 \pm 0.37$ & $4.67 \pm 0.61$ & $4.67 \pm 0.49$ \\
\hline $\mathbf{4}$ & $0.67 \pm 0.21$ & $0.50 \pm 0.22$ & $0.50 \pm 0.22$ & $0.33 \pm 0.21$ & $3.67 \pm 0.61$ & $2.83 \pm 0.40$ & $4.83 \pm 0.65$ & $3.67 \pm 0.42$ \\
\hline $\mathbf{5}$ & $0.17 \pm 0.17$ & $0.50 \pm 0.22$ & $0.67 \pm 0.21$ & $0.50 \pm 0.22$ & $2.83 \pm 0.75$ & $3.17 \pm 0.48$ & $3.67 \pm 0.84$ & $4.17 \pm 0.48$ \\
\hline Overall & $0.43 \pm 0.09$ & $0.53 \pm 0.09$ & $0.53 \pm 0.09$ & $0.33 \pm 0.08$ & $3.40 \pm 0.29$ & $3.50 \pm 0.2$ & $4.37 \pm 0.32$ & $4.40 \pm 0.21$ \\
\hline
\end{tabular}


Fig.1 Weather data for breeding (winter) and non-breeding (summer) seasons during the study period

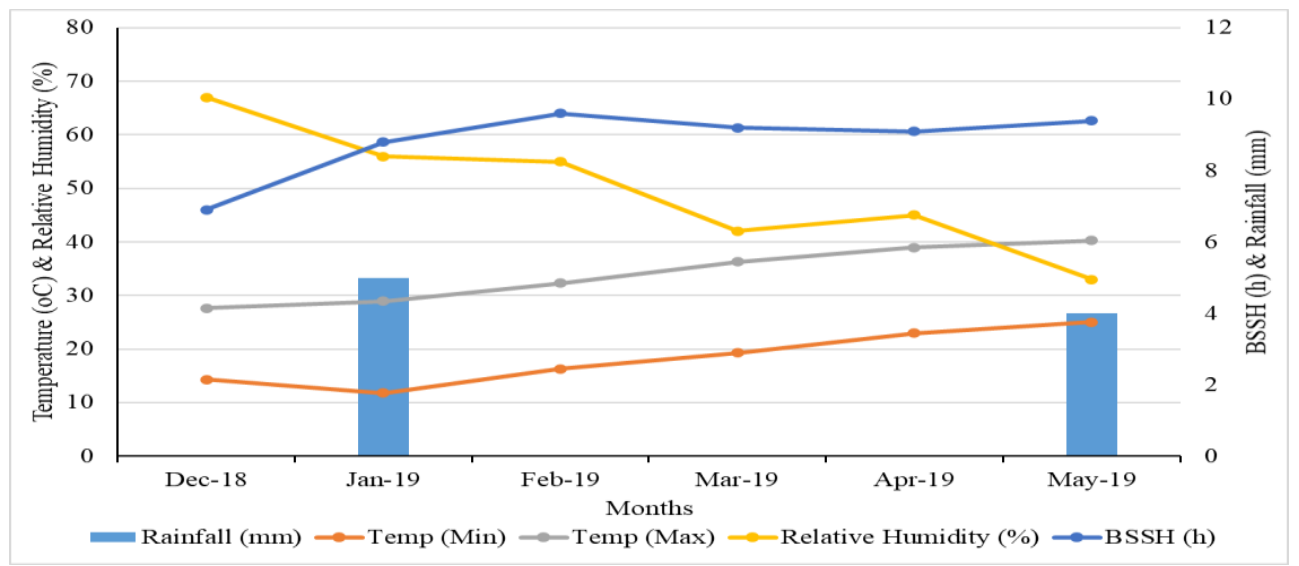

Fig.2 Comparative weather data of breeding (winter) and non-breeding (summer) seasons during the study period

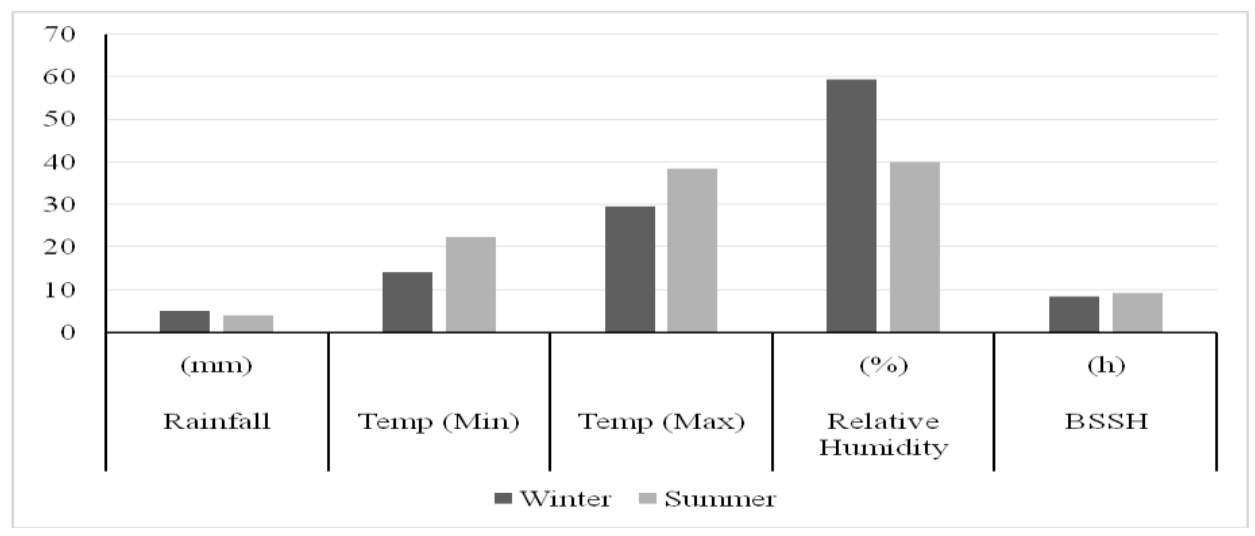

Plate.1 Semen collection from ram

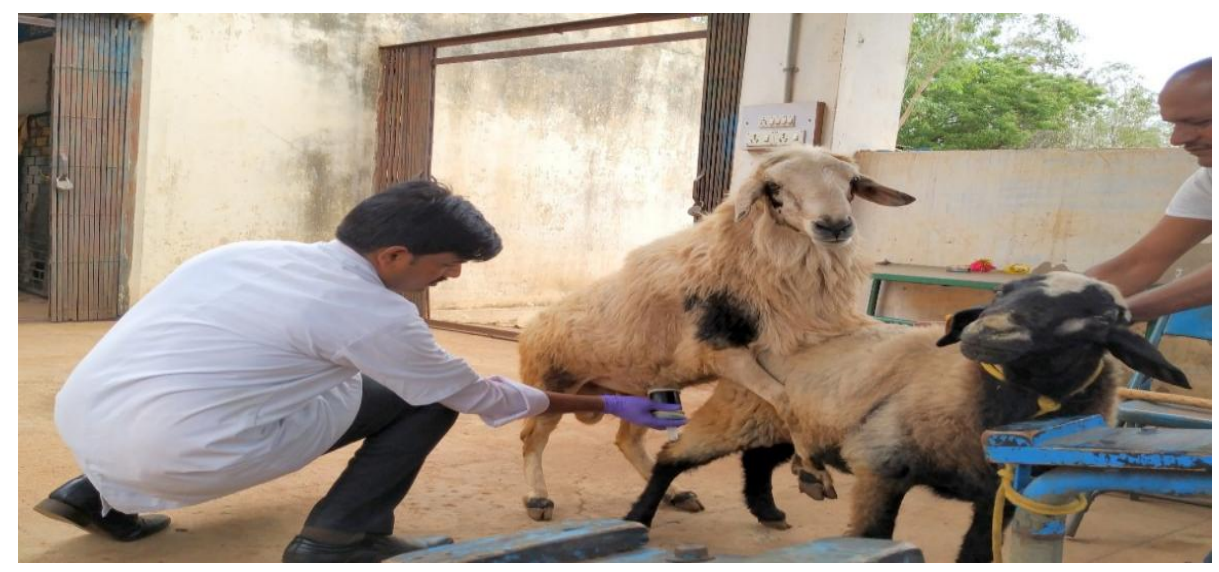


Plate.2 EosinNigrosin stain for live (white arrow) and dead (black arrow) sperm count

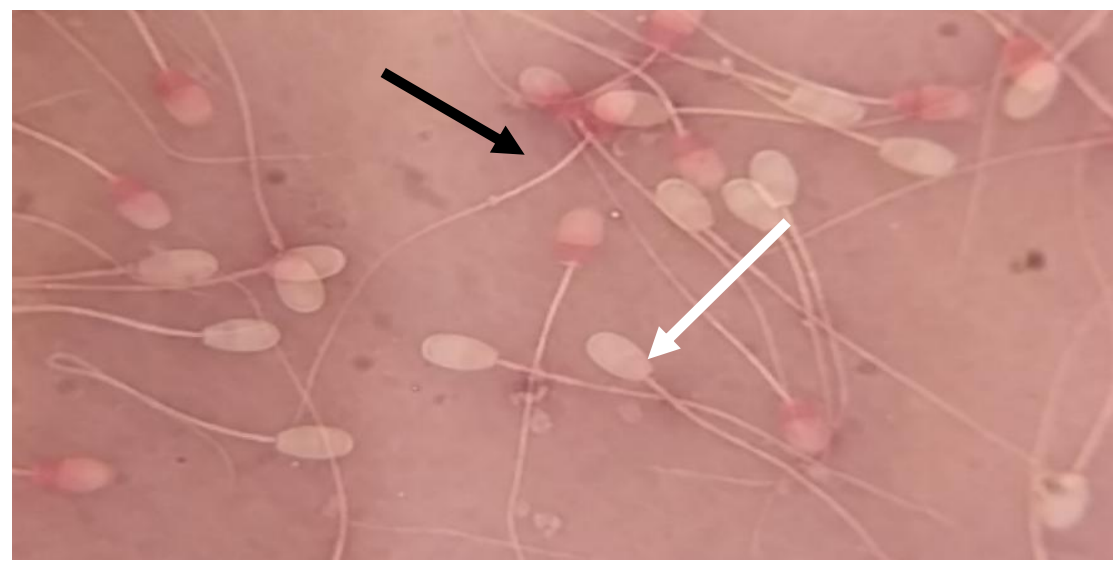

Plate.3 Giemsa staining to determine acrosome integrity: Intact acrosome (white arrow) and damaged acrosome (black arrow)

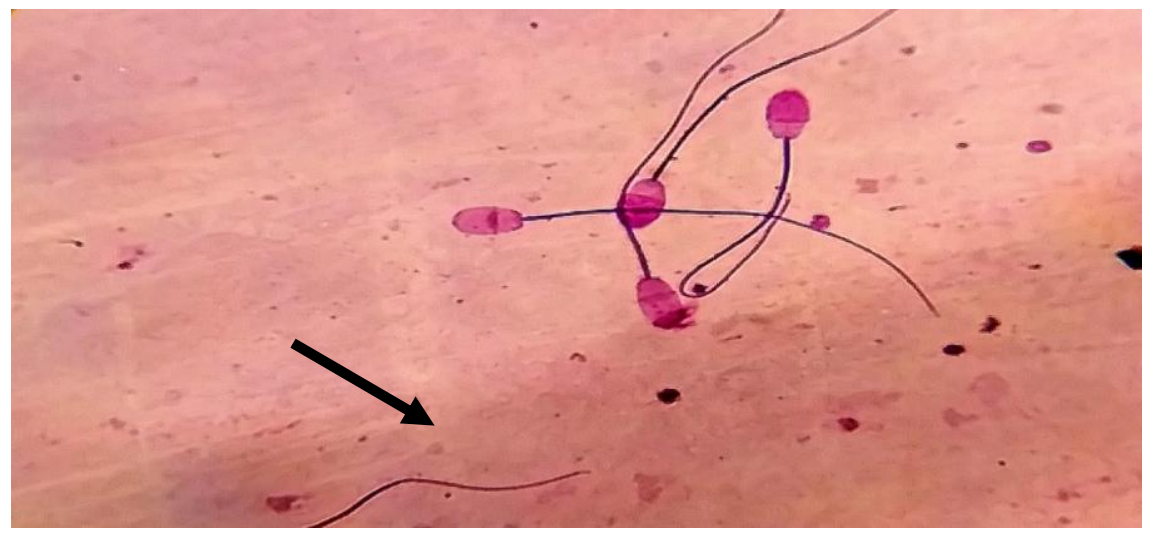

Plate.4 Hypo-osmotic swelling test: Swollen/ coiled sperm tails under phase contrast microscope (wet smear)

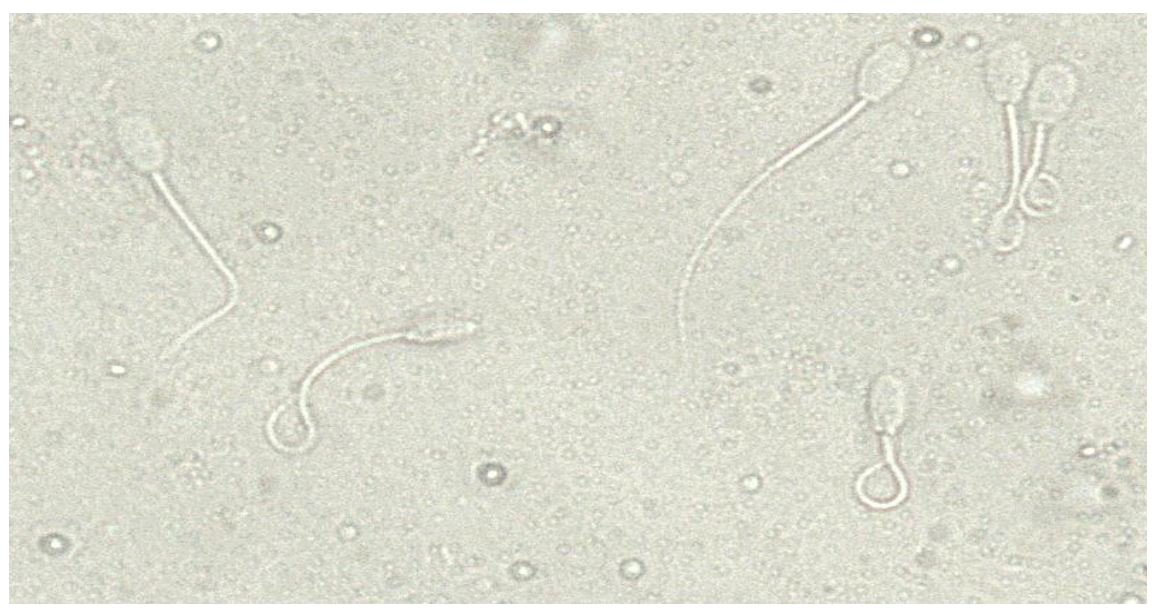


Plate.5 Rose Bengal staining for sperm abnormalities
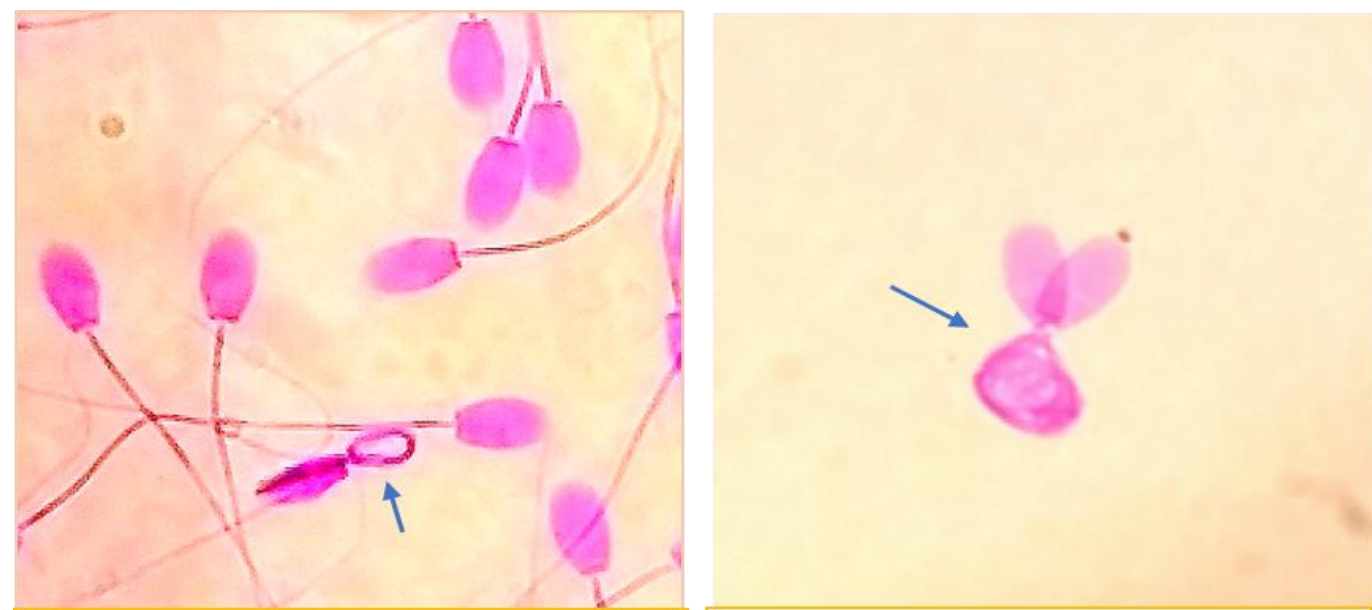

a. Coiled mid piece

b. Double head with tightly coiled tail
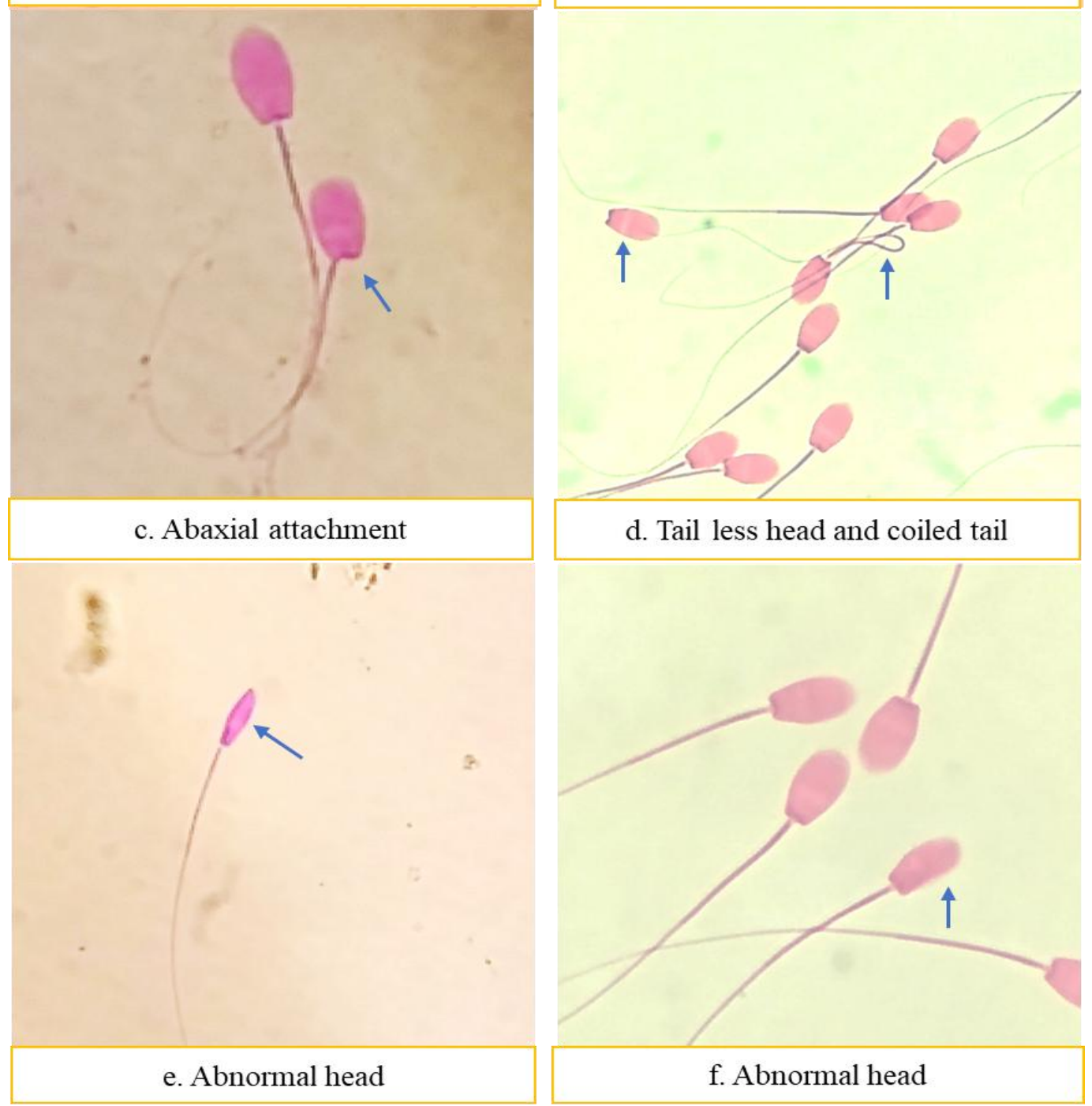
The present findings are in agreement with no seasonal effect but with lower abnormalities, as reported by Kaimal (2015) in NARI Suwarna rams. Similarly, this is also in agreement with Milczewski et al., (2015), Benmoula et al., (2017), and Chella et al., (2017) in Suffolk, INRA180 and Zulu breed respectively. Whereas, contradictory to the finding in Akkaramann and Awassi (Gundogan, 2006), Ghezel $\times$ Baluchi and Arkhar Merino×Ghezel (Moghaddam et al., 2012), Racka (Sarlós et al., 2013), Dorper (Malejane et al., 2014), Saint Croix (Santos et al., 2015), Ouled Djellal (Belkadi et al., 2017) and Chios rams (Ntemka et al., 2019). Findings of all these studies suggestive of significant variation in sperm abnormalities due to breed and season. As the present study did not show seasonal variation for sperm abnormalities, suggestive of equally good quality semen production both during breeding (winter) and non-breeding (summer) season in NARI Suwarna rams.

To conclude, despite significantly lower live sperm percentage during summer season NARI Suwarna rams can produce equally good quality semen in winter as well as summer season. Hence, can be used for semen collection during both the summer and winter seasons.

\section{References}

Abecia, J.A., Forcada, F. and GonzálezBulnes, A. 2012. Hormonal control of reproduction in small ruminants. Animal Reproduction Science 130: 173-179.

Al-Anazi, Y., Al-Mutary, M.G., Al-Ghadi, M., Alfuraiji, M.M., Al-himaidi, A.R. and Ammari, A. 2017. Seasonal variations in scrotal circumference and semen characteristics of Naimi and Najdi rams in Saudi Arabia. South African Journal of Animal Sciences 47:
454-459.

Ayala, A., Muñoz, M.F. and Argüelles, S. 2014. Lipid peroxidation: Production, metabolism, and signaling mechanisms of malondialdehyde and 4-hydroxy-2nonenal. Oxidative Medicine and Cellular Longevity 2014: 1-31.

Azawi, O.I. and Ismaeel, M.A. 2012. Effects of seasons on some semen parameters and bacterial contamination of awassi ram semen. Reproduction in Domestic Animals 47: 403-406.

Azawi, O.I., Al-Khashab, A.N.T.M. and Alkadoo, N.N.A. 2012. Effect of gonadotropin releasing hormone treatment on semen characteristics and enzymatic activities of Awassi rams in breeding and non breeding seasons. Iranian Journal of Applied Animal Science 2: 13-19.

Badi, A., Benmoula, A., El Khalil, K., Allai, L., Essamadi, A., Nasser, B. and El Amiri, B. 2018. Does advanced age affect reproductive variables, semen composition, and liquid semen storage during different seasons in Boujaâd rams? Animal Reproduction Science 197: 40-47.

Belkadi, S., Safsaf, B., Heleili, N., Tlidjane, M., Belkacem, L. and Oucheriah, Y. 2017. Seasonal influence on sperm parameters, scrotal measurements, and serum testosterone in Ouled Djellal breed rams in Algeria. Veterinary World 10: 1486-1492.

Belkhiri, Y., Bouzebda-Afri, F., Bouzebda, Z., Mouffok, C.E. and Djaout, A. 2017. Seasonal variations in reproductive parameters of Ouled Djellal rams in the East of Algeria. Indian Journal of Animal Research 53: 1407-1413.

Benmoula, A., Badi, A., El Fadili, M., EL Khalil, K., Allai, L., El Hilali, A. and El Amiri, B. 2017. Effect of season on scrotal circumference, semen characteristics, seminal plasma 
composition and spermatozoa motility during liquid storage in INRA180 rams. Animal Reproduction Science 180: 1722.

Cárdenas-Gallegos, M.A., Aké-López, J.R., Centurión-Castro, F. and MagañaMonforte, J.G. 2012. The breed and season effects on scrotal circumference and semen characteristics of Hair sheep rams under tropical conditions. Reproduction in Domestic Animals 47: e92-e94.

Chella, L., Kunene, N. and Lehloenya, K. 2017. A comparative study on the quality of semen from Zulu rams at various ages and during different seasons in KwaZulu-Natal, South Africa. Small Ruminant Research 151: 104-109.

D'Alessandro, A.G. and Martemucci, G. 2003. Evaluation of seasonal variations of semen freezability in Leccese ram. Animal Reproduction Science 79: 93102.

DeJarnette, J.M. 2005. The effect of semen quality on reproductive efficiency. Clin. North Am. Food Anim. Pract. Vet 21: 409-418.

Foote, R.H. 1978. Factors influencing the quantity and quality of semen harvested from bulls, rams, boars and stallions. Journal of Animal Science 47 Suppl 2: $1-11$.

Gómez-Brunet, A., Santiago-Moreno, J., Campo, A. del, Malpaux, B., Chemineau, P., Tortonese, D.J., Gonzalez-Bulnes, A. and LópezSebastián, A. 2008. Endogenous circannual cycles of ovarian activity and changes in prolactin and melatonin secretion in wild and domestic female sheep maintained under a long-day photoperiod. Biology of Reproduction 78: 552-562.

Gundogan, M. 2006. Some reproductive parameters and seminal plasma constituents in relation to season in Akkaraman and Awassi rams. Turk $J$ Vet Anim Sci 30: 95-100.

Gündoğan, M. 2007. Seasonal variation in serum testosterone, T3 and andrological parameters of two Turkish sheep breeds. Small Ruminant Research 67: 312-316.

Hamidi, A., Mamoei, M., Mirzadeh, K., Tabatabaei, S. and Roshanfekr, $\mathrm{H}$. 2012. Seasonal variations in semen characteristics in Arabic rams. Pakistan Veterinary Journal 32: 41-44.

Jasrotia, N. 2018. Supplementation of olive and almond oil in extenders for preservation of semen in NARI Suwarna strain of sheep. MVSc Thesis, KVAFSU, Bidar.

Jeyendran, R.S., Van der Ven, H.H. and Zaneveld, L.J.D. 1992. The hypoosmotic swelling test: An update. Archives of Andrology 29: 105-116.

Juma, F.T. and Al-Kassab, A.-H.O. 2009. Effect of seasonal variation on physical and biochemical properties of local Hamdni rams semen in Erbil region. Mesopotamia J. of Agric. 27.

Kadaganchi, A. 2017. Evaluation of semen preserved at refrigeration temperature by computer assisted semen analysis (CASA) of NARI Suwarna strain of sheep. MVSc Thesis, KVAFSU, Bidar.

Kaimal, P. 2015. Studies on reproductive traits, semen preservation at refrigeration temperature and its evaluation in NARI Suwarna strain of sheep. MVSc Thesis, KVAFSU, Bidar.

Kumar, N., Rai, B., Bhat, S.A., Kharche, S.D., Gangwar, C., Jindal, S.K. and Chandra, S. 2016. Effect of management system and season on semen freezability in Jakhrana bucks. Veterinary World 9: 199-202.

Malejane, C., Greyling, J. and Raito, M. 2014. Seasonal variation in semen quality of Dorper rams using different collection 
techniques. South African Journal of Animal Science 44: 26.

McGowan, M. 2019. Evaluation of the fertility of breeding males. In: David E. Noakes, Timothy J. Parkinson and Gary C.W. England (Eds.), Veterinary Reproduction and Obstetrics. Elsevier, pp. 619-634.

Milczewski, V., Chahad-Ehlers, S., Spercoski, K.M., Morais, R.N. and Thomaz Soccol, V. 2015. Quantifying the effect of seasonality on testicular function of Suffolk ram in lower latitude. Small Ruminant Research 124: 68-75.

Moghaddam, G.H., Pourseif, M.M. and Rafat, S.A. 2012. Seasonal variation in semen quantity and quality traits of Iranian crossbred rams. Slovak J. Anim. Sci 45: $67-75$.

Muniyappanavar, S. 2019. Effect of supplementation of Glutathione and $\alpha$ Tocopherol in TRIS and skim milk based extenders for preservation of ram semen at refrigeration temperature. $\mathrm{PhD}$. Thesis, KVAFSU, Bidar.

Muniyappanavar, S., Tandle, M.K., Vinay, P.T., Bijurkar, R.G., Suranagi, M.D., Kulkarni, S. and Bhagavantappa, B. 2020. Effect of supplementation of glutathione and $\alpha$-tocopherol in tris and skim milk based extenders on motility parameters of ram semen at refrigeration temperature. Int.J.Curr.Microbiol.App.Sci 9: 3063 3071.

Ntemka, A., Kiossis, E., Boscos, C., Theodoridis, A., Kourousekos, G. and Tsakmakidis, I. 2019. Impact of old age and season on Chios ram semen quality. Small Ruminant Research 178: 15-17.

O'Hara, L., Hanrahan, J.P., Richardson, L., Donovan, A., Fair, S., Evans, A.C.O. and Lonergan, P. 2010. Effect of storage duration, storage temperature, and diluent on the viability and fertility of fresh ram sperm. Theriogenology 73:
541-549.

Oláh, J., Kusza, S., Harangi, S., Posta, J., Kovács, A., Pécsi, A., Budai, C. and Jávor, A. 2013. Seasonal changes in scrotal circumference, the quantity and quality of ram semen in Hungary. Archiv Tierzucht 56: 102-108.

Perumal, P., Srivastava, N., Pande, M. and Ghosh, S.K. 2017. Counting Sperm Numbers. In: Srivastava, N. and M. Pande (Eds.), Protocols in Semen Biology (Comparing Assays), Springer Nature Singapore Pte Ltd., Singapore, pp. 73.

Pervage, S., Hassan, M.R., Ershaduzzaman, M. and Khandoker, M.A.M.Y. 2009. Preservation of liquid semen and Artificial Insemination in native sheep. J. Bangladesh Agril. Univ. 7: 305-308.

Rahman, S. 2014. Preservation of indigenous ram semen with skim milk diluent. PhD. Thesis, Bangladesh Agricultural University, Mymensingh.

Rosa, H.J.D. and Bryant, M.J. 2003. Seasonality of reproduction in sheep. Small Ruminant Research 48: 155-171.

Salhab, S.A., Zarkawi, M., Wardeh, M.F., AlMasri, M.R. and Kassem, R. 2003. Characterization and evaluation of semen in growing awassi ram lambs. Tropical Animal Health and Production 35: 455-463.

Santos, S.I., Sánchez-Dávila, F., VázquezArmijo, J.F., Ledezma-Torres, R.A., del Bosque-González, A.S., Palomera, C.L. and Bernal-Barragán, H. 2015. Changes in sexual behaviour and semen quality associated with age and type of enclosure of Saint Croix rams in different seasons of the year. Italian Journal of Animal Science 14: 678683.

Sarlós, P., Egerszegi, I., Balogh, O., Molnár, A., Cseh, S. and Rátky, J. 2013. Seasonal changes of scrotal circumference, blood plasma 
testosterone concentration and semen characteristics in Racka rams. Small Ruminant Research 111: 90-95.

Sikka, S.C. 2004. Role of oxidative stress and antioxidants in andrology and assisted reproductive technology. Journal of Andrology 25: 5-18.

Srivastava, N. and Pande, M. 2017. Protocols in Semen Biology (Comparing Assays). Springer Nature Singapore Pte Ltd, Singapore,.

Watson, P.F. 1975. Use of a Giemsa stain to detect changes in acrosomes of frozen ram spermatozoa. The Veterinary
Record 97: 12-15.

Zamiri, M.J. and Khodaei, H.R. 2005. Seasonal thyroidal activity and reproductive characteristics of Iranian fat-tailed rams. Animal Reproduction Science 88: 245-255.

Zamiri, M.J., Khalili, B., Jafaroghli, M. and Farshad, A. 2010. Seasonal variation in seminal parameters, testicular size, and plasma testosterone concentration in Iranian Moghani rams. Small Ruminant Research 94: 132-136.

\section{How to cite this article:}

Venkanagouda Doddagoudar, M. K. Tandle, R. G. Bijurkar, N. A. Patil, Ashok Pawar, Shrikant Kulkarni and Vinay Tikare. 2020. Semen Characteristics of NARI Suwarna Rams during Breeding (Winter) and Non-breeding (Summer) Seasons. Int.J.Curr.Microbiol.App.Sci. 9(08): 312-324. doi: https://doi.org/10.20546/ijcmas.2020.908.037 